\title{
A Look on Public Relations Education in Turkey
}

\author{
Yenğin D.A. ${ }^{1}$, Ilgın, H.Ö. ${ }^{2}$, Ertekin İ. ${ }^{3}$ \\ ${ }^{1}$ Didem Ataman YENĞiN, Istanbul Aydin University, (Turkey) \\ 2 Hicran Özlem ILGIN, Istanbul Aydin University, (Turkey) \\ ${ }^{3}$ İfan ERTEKiN, Istanbul Aydin University, (Turkey) \\ e-mail: didemyengin@gmail.com
}

\begin{abstract}
This study covers an examination of the "Public Relations" education and the respective issues of Communication Faculties in Turkey. It is evident that the public relations units are vital for all government bodies and commercial organizations in Turkey. However, the concept of 'public relations' is not properly comprehended and emerging issues lead to a questioning of the public relations education. After a general examination of the communication education in Turkey, the public relations education and its issues shall be examined to investigate the conditions for better education on public relations. In this study, the concept of public relations and its extensions have been discussed through a literature review and in line with such definitions, an online survey (questionnaire method) has been conducted with the teaching staff, students and graduates of public relations departments as random participants and the data has been analyzed. The population of the study comprises the public relations students in Turkey. In addition to the analyses and examinations in this study, the aim has been to reveal the structure of public relations education in Turkey and to generate solutions for issues.
\end{abstract}

Keywords: Public Relations, communication, public relations education, Turkey

\section{Introduction}

The world and communication are integral. Communication has recreated the world in the image of a global village, to quote McLuhan. Communication cannot exist without man and man cannot exist without communication. At this point, communication has become indispensable for the individuals in a society. Although the positioning of the interdisciplinary structyre that communication is said to have involves certain issues, "the path followed grants it a supra and sub disciplinary position, allowing the meaning of life to be expressed through 'experience' (Tellan, 2011; 15). The effect of economic, political, cultural and technological changes emphasized the significance of mass communication, particularly influencing and reinterpreting through this effect the technologies such as radio, television and cinema, dubbed new media, and letter, telegram, newspaper and photography, dubbed the traditional media. In this context, the communication became an independent and interdisciplinary field of study with the work of "Shannon and Weaver dated 1949 titled 'Mathematical Model of Communication', where the early definitions emphasize the change caused by mass communication tools and the mass communication style on human affairs and social life practices. It has been frequently suggested that mass communication, assumed by the traditional interpretation to be organized on the basis of effects, rituals, cultural indicators and innovations, holds the economic aim of profit and the political aim of freedom. As indicated by Elliot, mass communication in the context of the transfer of organized meaning, is often not communication. Mass communication is more of 'observation' and the mass communication observer is a group monitor rather than a participant or information recipient" (Tellan, 2011: 16). With the phenomenon of social physics defined by Auguste Comte in the 1800s, the study of individuals in a society has gained pace. With the popularization of mass communication tools, the practices for individuals to communicate have also been renewed. Each renovation brings about new social problems. At this point, academic studies to produce solutions for such problems have been carried out in conjunction with sociology. Communication faculties have focused their education on human mass communication tools, social mass communication tools and mass communication tools. Within the context of these topics, the departments established under the faculties have and still do search for solutions to such problems. While it is observed that, with respect to the interdisciplinary nature of communication, academics 
have tended to gain expertise on sociology, psychology, anthropology and political sciences and to focus on theories, while the mathematical model remained influential until late 20th century. It is seen that the studies on communication are mostly considered a social science and an understanding of education is developed in this respect, increasing certain practical studies in the implementation of radio, television, cinema and newspaper.

While the world at large evaluates the interdisciplinary nature of communication, developments, although slow, have taken place on the study and education of communication in Turkey. A look at the overall historical process of communication education in Turkey shows that the first education work started with the journalism schools. As expressed by Arık (2011); The establishment of Istanbul School of Journalism, through the initiatives of Fehmi Yayla in 1948 and providing degree-level education, the establishment of İstanbul University, Faculty of Economics, Journalism Institute in 1949 and the starting of education in the Higher School of Press and Media under the Faculty of Political Sciences in Ankara University in the 1965-66 academic term in Ankara and the opening of three private schools of journalism in the 60 s subsequent to these developments are considered significant. Since 1966, developments have taken place on education in the context of private schools. Subsequent to these developments, the Faculty of Communication has been established in the Anadolu University in Eskişehir in 1972, while in 1992, the higher schools of press and media have transformed into faculties of communication in line with a law enacted, ensuring the establishment of new communication faculties and an increase in the number.

With the emergence of the concept of industrial society and various activities of production and consumption, the power of public relations has been utilized to ensure greater effectiveness of messages on target masses. The property of message as information has now been replaced by production and consumption dynamics. Communication is utilized for consumption purposes with the visual images generated by design. Messages created for advertisement purposes utilize rhetorics to convince individuals to consume. If advertising is important for an organization, the phenomenon of public relations is equally important for the organization to successfully communicate with the target audience in an accurate, healthy and successful manner. At this point, public relations emerge as a significant factor in bolstering the effect of communication and its proper management, realizing the strategic communication management between the organization and its target audience, as defined by James Grunig" (Grunig, 2005: 15). Moving from the same point, convincing the target audience in public relations activities is associated with rhetorics, drawing attention on the structure of the address used to receive the consent of the target audience. Influenced by the necessities of the age and in a constant effort for innovation, public relations accelerated its development by transition to modernization, the initialization of the capitalist structure, globalization and concepts related to globalization.

\section{Theories on Public Relations}

As a field dealing with, evaluating and synthesizing several disciplines, public relations is an interdisciplinary field that cannot be examined within a singular definition. Its nature leads to confusion in its definition, although the fact that public relations is in relation with many disciplines influences its expansion as well. One of the most significant reasons for such variety in definitions is also triggered by variation in activities through developments and changes in the historical process. At this point, every change in social-cultural and economic structures further increased the need of organizations for public relations, leading to variations in definitions as well as activities in public relations. This interdisciplinary nature does not only refer to the inclination and utilization of public relations from other disciplines. Public relations implement its ability to melt down information from various disciplines in the same pot to integrate and combine as to complement this concept.

The capitalist system being present since the 18th century, the inclusion of mechanization and division of labor in this process has led the individual into a new search for ways to express themselves. With the emergence of class structures in the 19th century, individuals have attempted to complement their places in the new class structures, eliminating previous differences between such structures. As the principle of maintaining a delicate balance between capital holders as parties of the capitalist system and the worker class for the continuity of the system, meaning the necessity for the worker class to act in line with the benefits of the capital holders, it led to further softening of the manners of communication. At this point, the new definition of public relations has been described the communication of private companies and public agencies with their physical and social environments 
(Okay et al., 2003: 4). This concept of public relations, known to originate from the USA, has a history of a hundred years and is the source of initial definitions. In this context, these definitions on public relations originate from the idea of "ensuring cohesion".

In his paper titled 'Crystallizing Public Opinion' published in 1923, Edward Bernays, the father of Public Relations as a field, described public relations as ensuring cohesion and understanding between the public and the organization" (Okay et al.,2003: 5). E. Bernays expressed the period of 1940-50 as the time when companies developed more professional perspectives, focused on social affairs to create motivation, mediation and public opinion, developing active relations to achieve modernization and attain the organization's desires where organizations interacted more with their environment and literally socialized.. Since 1960, with the effects of economic life, public relations has been considered an important part of management and gained a structure more integrated with business management; these days when public relations and business management are named together, Bernays says this causes issues in public relations becoming an independent discipline.

According to the definition by Rex Harlow in 1976, public relations is an administrative function aiming to create communication, understanding, cooperation and acceptance-based bonds between an organization and its target audience; it is also related to administrative issues, allowing company management to be informed about public opinion and respond accordingly; emphasizes the need for the company management to act towards the public's benefit; foresees trends to help the company keep up with change; benefits from research and moral communication techniques as fundamental purposes" (Theaker, 2006: 16).

Grunig and Hunt define public relations as; "the management of communication between an organization and the public concerning that organization" (Grunig, 2005: 15). As seen in this definition, public relations is associated with the ability of an organization to communicate with internal and external target audiences in order to achieve its goals and aims and its ability to plan, execute and evaluate this process of communication.

In general, considering the four models on public relations, it is possible to see what the history of public relations is and how it changed and developed throughout different periods. The general structure and features on these models have been explained as follows (2005: 308-312.): The leading representative of Press agency/promotion model is P.T. Barnum. In this model, the aim is to conduct propaganda and the success criteria of public relations are associated with its place in the media. The principle is to maintain customers in any way rather than telling the truth. A one-way communication from the source towards the recipient, the model does not consider research and target audience's opinions significant and involves no bilateral understanding. Its current areas of use include sports, theater, product promotion and celebrities. The period of 1850-1900 can be said to be the time this model was effective. Public information model is represented by Ivy Lee. By its general structure, the model considers the activity of public relations expert as the obligation of relaying important information to company employees and necessary parties. This model was effective in the 1900-1920 period and includes a one-way communication from the source to recipient in order to propagate information. The accuracy and authenticity of information is important, which makes this model different from the press agency model. The current application areas of this model include nonprofit organizations, companies and government. This is a model used in crisis situations. Two-way asymmetric model is represented by Edward L. Bernays. It aims for and considers scientific persuasion and change in public attitude and behavior. It is informative. This model involves a twoway communication from source to recipient and back with unbalanced effects and has been effective in the 1920-1960 period. The most important addition of this model is 'feedback'. We see environments and agencies with competition element as areas of implementation. Two-way symmetric model is expressed as ideal public relations and its representatives are Bernays, public relations trainers and professional associations. This model, covering the period of 1960 and afterwards, includes communication based on mutual understanding between different groups, mutual, two sided and balanced. By this nature, evaluations of understanding are conducted and serves as informative and mediator. Management is not centralized. Based on mutual dialogs and compromises, this communication model does not find many real life applications. Its current areas of application are limited to business environments and agencies under strict legal scrutiny. To state the areas of activity for public relations in this context, "in-house communication, corporate public relations, media affairs, inter-corporate relations, public affairs, communication with society/social responsibility, investor relations, strategic communication, monitoring environmental factors, crisis management, drafting, 
publication management, activity management and fairs" (Theaker,2006,p.21) can be listed.

These four models by Grunig and Hunt show the periodical developments of public relations and the basis for the "perfect public relations theory". In this context, "the question of perfection is to attempt to resolve how the function of communication is shared theoretically and in terms of program in order to achieve the best possible activity" (Akbulut, 2008; 25). It would be accurate to say that the understanding of perfect public relations centralizes the two-way communication, and moves away from the understanding of 'artisan' with one-way communication.

It is possible to define public relations, which has been defined hundreds of times, based on these definitions. In general, the qualities of public relations can be defined as: the need to be performed by experts, ensuring the sharing of information with management in line with transparent and healthy analyses, forming all activities in line with the organization's needs, conducting activities while bearing in mind the need for image and reputation management in public eye, remembering the basic principle of involving mass communication tools, positioning close to senior management to ensure effective and rapid decision-making.

Also with respect to definitions, looking at the mutual acts and decisions defining public relations, as stated by Özkan (2009: 17), the following features stand out; pre-design; public relations is an activity to influence a certain group and to draw attention and is conducted with a pre-design. Planning; public relations is a systematic activity in which the time, place and aim are planned ahead and solutions developed for possible problems. Performance; public relations is an activity conducted in line with its purpose and accurately, based on performance, which should respond to public expectation and carry elements of reality and trust. Public benefit; public relations does not only conduct activities focused on the organization's interests, but also considers public benefit. Otherwise, the loss of reputation in public eye and trust as well as social reaction may follow. Two-way communication; public relations cannot achieve its goals without two-way communication, the feedback received for the message delivered to the target audience is critical for the course and success of public relations activities. Management function; successful and effective public relations is strategically positioned close to senior management, able to move alongside decision-making mechanisms. Public relation is a part of the decision-making process and, where necessary, of strategic value in consultancy and problem-solving.

\section{Curriculum in Public Relations Education and Public Relations Education Curriculum in Turkey}

There are various classifications on the developments relating to the history of public relations in Turkey and the world in general. It is possible to consider public relations in Turkey in four periods of outlines. These periods are;

1. 1919-1960 period; the period involving the explanation of Ataturk's work and revolution to the public. The period's newspapers İrade-i Milliye, Hakimiyet-i Milliye, and establishment of Anadolu Ajansı, ( http://stratejikileti.blogspot.com.tr/2014/01/turkiyede-halkla-iliskilerin-gelisimi.html- access: 24.05.2016).

2. 1960- 1980 period; the period in which public relations professionalized, developed and became a profession. The most significant indicators of this are the establishment of State Planning Agency in 1960, realization of the Central Government Research Project (MEHTAP Project) in 1962, the first classes on public relations in Ankara University in 1966, as of 1969, companies like Koç Holding, Sabancı and Eczacıbaşı have created public relations units to initiate and develop public relations as leaders in the field. Furthermore, "the Public Relations Association has been established in 1972. In 1974, A\&B, the first public relations agency in Turkey, has been opened." (http://stratejikileti.blogspot.com.tr - access 23.03.2016, time: 16:11).

3. 1980-2000 period; public relations further professionalized, public and private organization assigned greater significance to public relations, the importance of public relations education gained greater significance. Public relations and journalism departments formed as of 1980 . Public relations have been utilized in the political world as of 1983. The Izmir Public Relations Association has been established in 1985. IMAGE Public Relations Agency has been established in 1987. The Ankara Public Relations Association has been established in 1990. "In 1992, the communication faculties 
have been established and public relations education has been initiated as a separate department in these faculties" (Peltekoğlu, 2007: 129).

4. Period of $\mathbf{2 0 0 0}$ and afterwards; In addition to agencies operating at international level, the number of faculties and vocational schools as well as master's and PhD programs on this field has increased. There have also been developments in the academic studies, curricula and legal regulations in Turkey. The Public Relations Association, which took important steps towards establishing public relations as a profession in Turkey, has been renamed Turkish Public Relations Association (TÜHID). In 2005, a center called Prime Ministry Communication Center (BIMER) where people can express complaints and opinions through the call line 150 for patient rights has been established. The education in Turkish universities started as communication and journalism education. As of $1987^{\star} 1988$ period, the 'Public Relations and Promotion Departments' have been established. In 1992, the Higher Schools of Press have reformed into Communication Faculties" (Enerdağ, 2004: 54).

According to general assessments of Asna, the initial public relations classes have been established without planning and through trial\&error. As stated by Asna on this issue (2012: 225-227); the number of students applying and admitted to communication departments was too high, inadequate in quality and quantity, the students applied without known the content of education in communication faculties and incidentally, such faulty applications would reflect negatively on future professional life, the possibility of remedying the fundamental shortcomings of students during university education was too low, the teaching staff in universities was not adequately qualified" . In this context, steps to be taken in public relations education have been summarized by Asna as follows; Students who are successful in the examination should be interviewed by the department, the number of students enrolled should be kept between 30 and 50, the students admitted should be evaluated by physical features, foreign language qualification, personal interests and skillls, universities should provide all technical standards to provide proper education in communication faculties and observe similar care and conditioning in the selection of academic staff, universities should provide periodical support and assessment to contribute to the development of their academic staff, expert cameramen, directors and similar technical experts should be allowed to give guest lectures at universities and additionally "introduction to culture courses (law-sociology-economy etc) should only be taught to junior classes, second and third year classes receiving common professional courses should also receive the journalism, radio-tv, public relations, advertising, public opinion studies classes, senior classes should be divided into modules of technical implementation- laboratory work. The period of education in English should be set to at least $40 \%$ of general education, course timing should follow theory in the morning, language and mechanical teaching in the afternoon in a full day" (Asna, 2012. p.227-228).

With respect to period, examining the public relations education in Turkey after 2000 as an example of studies and evaluations compared to USA and European countries, Becerikli (2004) and Vural and Yurdakul (2004) determine that; the universities in Turkey have higher course credits, mandatory classes outnumber optional classes, Turkish universities have more common optional classes and a wider scale of optional classes are offered despite a lack of sectorial variety. Further assessment of educational programs indicates that Turkey, similar to USA is in a structure aiming to protect the positive image of public relations by distancing from criticism.

There are two contrasting points on public relations education. This contrast is associated with a popular understanding of higher theoretical and lower practical education. In particular, employers, influenced by industrial expectations, express that graduates 'don't know much' as they lack practical information. As stated by Erdoğan (2007: 22-23); with this expectation for practical education, the industry's expectation will be fulfilled and the thinking individual will be replaced by a functional robot with a life based on "doing". Individuals moved away from questioning and thinking are obliged to perform their duties and eliminated as threats to the system.

The International Public Relations Association (IPRA) having great significance in the process of establishing associations as one of the most important indicators of professionalizing in public relations explains the issue with three intersecting circles to set certain standards in education. These circles are explained as follows in the Golden Books Series issue-7 by Black (1998: 9); the central circle consists of topics forming the foundation of public relations, the second circle comprises issues of significance for the field of communication, while the outermost circle states the information and topics that interdisciplinary public relations and an ideal public relations expert should have. As stated 
by Erendağ (2004: 69) in the studies on curriculum; interdisciplinary aspect, ability to keep up with information technologies, significance of providing applied courses, necessity of internships, necessity of speaking a foreign language, the nature of teaching staff in taking an effective role for the success of curricula, the industry's significant role in public relations education are highlighted.

At this point, Kocabaş, Pira and Sohodol indicate changes in the understanding of the public relations education in addition to the curricula in Turkey will be significant for the quality of education, and academics, implementors and students have duties in increasing this quality of education and go on to say (2004: 229-233); the primary role of educators is to have academic and professional experience and knowledge with the view of life long education and development. Ensuring balance in combining academic and applied knowledge, joining theory with practice, constantly keeping themselves up-to-date, following activities, meetings, congresses and symposiums on public relations, becoming members of professional organizations to join their academic life with sectoral activities, making students a part of course topics by encouraging presentations, discussions, group work, idea sharing and thus allowing the creation of new projects and examination of existing ones and inviting guests on related topics to bring the academy together with the industry are the expressed requirements. Furthermore, finding and using materials to make classroom teaching fun is stated as another important detail. The primary role of students is to improve their foreign language, to constantly read in public relations and other fields of interest, to keep up with current issues and technology, to closely follow international developments on public relations, to attend congresses, symposiums and panels on public relations, to follow public relations projects and attend relevant contests, to be individuals who can research, think analytically, make decisions, take risks, manage crises, speak and write effectively, and adopt professional codes of ethics in order to improve their personality. In the implementation phase, they should believe in public relations and support the field through academic and association work, be encouraging and supportive with respect to internships, and prioritize graduates of public relations in employment options.

\section{Methodology}

The subject of this study, based on the perspective that public relations education should build on mutual decisions of educators, implementors and even students, is to evaluate public relations education and its issues in the communication faculties in Turkey and to provide recommendations for solutions. This study investigates the opinions of academics, implementors, students and graduates on public relations education and the profession. In this study, it is expected that academics and implementors shall consider the expectations and desires of students and graduates in reaching a consensus on the standards of public relations education. The academics, implementors, students and graduates reaching a consensus is critical for the field to advance and improve in the right direction. Consequently, to examine the opinions of academics, implementors, students and graduates jointly, the data have been analyzed using survey (questionnaire) method and semi-structured interview, e-mail response methods.

The aim of this study is to define public relations education in Turkey in relation to the opinions of academics, students and implementors, revealing similarities and differences with the aim of establishing the desired standards in public relations education. This chapter explains the study population, the development of the data collection tool, the statistical method and techniques used for data collection, analysis and interpretation. The study method is literature review and survey (questionnaire) with random population prepared online. Using the determination established in this way, the online survey form has been created and sent to academics, featuring three demographic questions, four open-ended questions and sixteen judgments complying with the Likert scale. Similarly, the survey forms given to students included four demographic questions, followed by three open-ended questions and twenty nine judgments complying with the Likert scale. The population of the study comprises the public relations students and graduates in Turkey.

To determine the attitudes, behavior, feelings and thoughts of individuals, one of the methods used in the study is the survey (questionnaire) method. "Questionnaire is a research method with the most reliable results and the minimal error margin, if necessary care is exercised in forming the sample group, taking the survey, implementation and assessment" (Aziz, 2015: 83). The survey questions are intended for the academics and the current/previous students of public relations and advertising, public relations and promotion departments in communication faculties. The opinions and thoughts of academics in such departments as well as current/previous students and graduates on the 
issue and the current situation have been gathered via the online questionnaire. The aim of this online questionnaire is to determine, with the view that in a free environment, individuals can more openly express their wishes and expectations, the expectations on the current situation or what they are satisfied with, their evaluations on the desired public relations education, in order to attain data on determining points with positive or negative opinions. In this context, the study attempts to determine any variation in opinions on the principles of the 4-year faculty education, the current course structures, the connections of universities with the industry, the opinions and thoughts of teaching staff and students on course structures, their view of public relations as a profession, their opinions on employment after receiving education on public relations, views on internship and assessments of connections between universities and professional organizations. A student survey comprising four demographic questions, three open ended questions and twenty nine questions with Likert scale is available. The study has been conducted with random participants of students and academics by forming online survey forms and analyzed in light of the data. Furthermore, the survey form for academics also comprises three demographic questions, four open-ended questions and sixteen Likert scale questions.

\section{Findings}

The survey using online forms has been conducted with random participants between January 2017 and April 2017, the data attained has been analyzed using the SPSS 23.0 package software to establish the study findings. Survey data has been analyzed based on the responses of 529 participants. The attained data has been analyzed by percentage and frequency methods. The results have been received and evaluated in charts. When evaluating survey questions, factor and reliability as well as difference and relation analyses have been implemented and the charts covering the study subject have been provided respectively in the survey.

\section{Results of Descriptive Analyses on the Features of Survey Participants}

The findings on 529 participants of the survey are provided in Table 19. Of the participants, $60.7 \%$ was female, $39.3 \%$ was male, $48.8 \%$ was aged 22 to $26,79.6 \%$ was a bachelor's degree holder and $55.8 \%$ was students.

\section{Explanatory Factor and Reliability Analysis}

Prior to conducting the factor analysis for the scale used in the study, the statements "I believe the number of theoretical course hours in our department should be reduced", "I believe the number of applied course hours in our department should be reduced", "I agree with the university requiring mandatory internship", "The high number of communication faculties creates problems of employment in public relations field" and "I believe there are significant differences in public relations education in state and private schools" were found to be negative and have been reversed $(1=5,2=4,3=3,4=2$, $5=1$ ). Upon completion of this process, the fundamental factor analysis has been implemented to the scoring attained from the reactions of 529 participants in order to establish the factor structure.

To test the conformance of data set to factor analysis, Kaiser - Meyer - Olkin (KMO) sample adequacy test and Bartlett globality test have been implemented. The KMO value was determined above the acceptable threshold of 0.70 with 0.75 , Bartlett globality test was over 0.50 and meaningful at significance rate of 0.05 , thus conforming with data set factor analysis. The resulting KMO coefficient shows the data is suitable for analysis. The principle of variance explanation rate of 0.50 or above has been followed. Questions have been analyzed using fundamental components method and Varimax rotation method. The expressions with sample group adequacy below 0.50 , remaining as the only item under a factor or having a factor weight below 0.50 , namely "I find it suitable that applied courses in public relations education are given by industry participants", "I agree with a greater presence of ethical codes in the curricula for public relations education", "I believe the number of theoretical courses in our department should be reduced", "When I graduate, I believe l'll get the returns for high quality of education from our department in the business life", "After graduating, I am planning to work in the public relations industry in relation to my department", and "I agree with the University requiring mandatory internship", have been removed from the analysis and factor analysis resulted in 7 factors with an eigenvalue of 1 or above. The dimensions have been named respectively as; "Factor 1 Questions on considering theoretical and applied classes in public relations departments adequate, 
the adequacy of the quality of public relations education received in such departments for employment and in global standards", "Factor 2 - Questions on successful use of new technologies in curriculum, considering wages paid to public relations workers to be good, the employees in public relations being mainly women, believing the university aids students in finding internships", "Factor 3 - Questions on agreeing with the use of professional foreign language courses and foreign resources and considering working in this area while studying public relations to be more effective", "Factor 4 - Questions on considering the universities being connected with professional organizations beneficial, internship being beneficial to those who will be employed in public relations and elective courses being higher in number than mandatory courses would be more beneficial", "Factor 5 - Questions on agreeing with the University's requirement of mandatory internship from students in public relations departments and considering public relations employees as prestigious", "Factor 6 - Questions on intentional and voluntary selection of public relations departments and considering the education in private and state universities to be different" and "Factor 7 - Questions on considering too many communication faculties opening up will create employment issues in public relations and there is no difference between the education state and private universities in this respect". The total declared variance has been found as $72.6 \%$. The factor weight of items is between 0,533 and 0,899 .

The questions with established forms of categorization have been combined in the reliability analysis. Cronbach Alpha value has been used to calculate internal consistency. The reliability coefficient is seen to be 0.68 . This value complies with the lower threshold criteria of 0.60 in the literature (Cronbach, 1990; Sekaran, 2000). Therefore, the Table 21 shows that the scale used in the study has internal consistency.

\section{Normal Distribution Analysis}

The normality of the distribution of opinions on variables has been analyzed with the Kolmogorov-Smirnov test. The test results show that the variables demonstrate no normal distribution $(p<0.05)$. Therefore, non-parametric methods have been used in analyses.

\section{Difference Tests Conducted for Collected Data}

\section{Analysis of Difference by Gender}

The relation between the scale and dimensions and gender has been analyzed with the Mann - Whitney $U$ Test. The analysis results are provided in Table 1.

Table 1. Analysis of Difference by Gender

\begin{tabular}{|c|c|c|c|c|c|c|c|}
\hline Dimension & Gender & $\mathbf{N}$ & $\begin{array}{l}\text { Average } \\
\text { of Lines }\end{array}$ & $\begin{array}{c}\text { Total of } \\
\text { Lines }\end{array}$ & $\begin{array}{c}\text { Mann - } \\
\text { Whitney U } \\
\text { Value }\end{array}$ & $\begin{array}{c}Z \\
\text { Value }\end{array}$ & $\begin{array}{c}p \\
\text { Value }\end{array}$ \\
\hline \multirow{3}{*}{ F1 } & Female & 321 & 217.90 & 69945.00 & \multirow{2}{*}{18264.000} & \multirow{2}{*}{-8.831} & \multirow{2}{*}{0.000} \\
\hline & Male & 208 & 337.69 & 70240.00 & & & \\
\hline & Total & 529 & & & & & \\
\hline & & & & & & & \\
\hline \multirow{3}{*}{ F2 } & Female & 321 & 230.47 & 73979.50 & \multirow{2}{*}{22298.500} & \multirow{2}{*}{-6.499} & \multirow{2}{*}{0.000} \\
\hline & Male & 208 & 318.30 & 66205.50 & & & \\
\hline & Total & 529 & & & & & \\
\hline & & & & & & & \\
\hline \multirow{3}{*}{ F3 } & Female & 321 & 282.91 & 90814.00 & \multirow{2}{*}{27635.000} & \multirow{2}{*}{-3.410} & \multirow{2}{*}{0.001} \\
\hline & Male & 208 & 237.36 & 49371.00 & & & \\
\hline & Total & 529 & & & & & \\
\hline \multirow{3}{*}{ F4 } & Female & 321 & 234.00 & 75115.00 & \multirow[b]{2}{*}{23434.000} & \multirow[b]{2}{*}{-5.876} & \multirow[b]{2}{*}{0.000} \\
\hline & Male & 208 & 312.84 & 65070.00 & & & \\
\hline & Total & 529 & & & & & \\
\hline F5 & Female & 321 & 268.06 & 86047.00 & 32402.000 &,- 593 & 0.553 \\
\hline
\end{tabular}




\begin{tabular}{|c|c|c|c|c|c|c|c|}
\hline & Male & 208 & 260.28 & 54138.00 & & & \\
\hline & Total & 529 & & & & & \\
\hline & & & & & & & \\
\hline \multirow{3}{*}{ F6 } & Female & 321 & 239.18 & 76777.50 & \multirow{2}{*}{25096.500} & \multirow{2}{*}{-4.916} & \multirow{2}{*}{0.000} \\
\hline & Male & 208 & 304.84 & 63407.50 & & & \\
\hline & Total & 529 & & & & & \\
\hline & & & & & & & \\
\hline \multirow{3}{*}{ F7 } & Female & 321 & 239.14 & 76764.00 & \multirow{2}{*}{25083.000} & \multirow{2}{*}{-4.987} & \multirow{2}{*}{0.000} \\
\hline & Male & 208 & 304.91 & 63421.00 & & & \\
\hline & Total & 529 & & & & & \\
\hline \multirow{4}{*}{ Scale General } & & & & & \multirow{3}{*}{20030.500} & \multirow{3}{*}{-7.791} & \\
\hline & Female & 321 & 223.40 & 71711.50 & & & \multirow{2}{*}{0.000} \\
\hline & Male & 208 & 329.20 & 68473.50 & & & \\
\hline & Total & 529 & & & & & \\
\hline
\end{tabular}

The analysis of Table 1 is as follows:

Factor5 (F5); Agreeing with the University requiring mandatory internship from students in public relations departments and considering public relations employees as prestigious show no statistically meaningful variation by gender $(p>0.05)$.

However, the factors displaying statistically meaningful variation by gender are as follows: Factor1 (F1); the general status of the expressions 'finding the theoretical and applied course hours in public relations departments to be adequate' and 'the education received from such departments being adequate in quality and standards for employment and at global standards' show statistically meaningful variation by gender $(p<0.05)$.

Factor2 (F2); the general status of the expressions 'the successful use of new technologies in curriculum', 'considering wages paid to public relations employees to be good', 'public relations employees being mostly women', 'believing the university aids its students with respect to internship' show statistically meaningful variation by gender $(p<0.05)$.

Factor3 (F3); the general status of the expressions 'agreeing with the professional foreign language courses and use of foreign material in public relations education' and 'considering it more effective to work in public relations while also studying it' show statistically meaningful variation by gender $(p<0.05)$.

Factor4 (F4); the general status of the expressions 'considering the university being connected with professional associations beneficial', 'the internship being beneficial to those that will be employed in public relations' and having more elective courses than mandatory ones will be beneficial' show statistically significant variation by gender $(p<0.05)$.

Factor6 (F6); the general status of the expressions intentional and voluntary selection of public relations department and considering the public relations education in state and private universities to be different show statistically significant variation by gender $(p<0.05)$.

Factor7 (F7); the general status of the expressions the high number of communication faculties will lead to employment issues in public relations field and considering the public relations education in state and private universities to be indifferent in this respect show statistically significant variation by gender $(p<0.05)$.

According to these results, women have higher levels in finding the theoretical and applied course hours in public relations departments to be adequate' and 'the education received from such departments being adequate in quality and standards for employment and at global standards (F1), the successful use of new technologies in curriculum', 'considering wages paid to public relations employees to be good', 'public relations employees being mostly women', 'believing the university aids its students with respect to internship (F2), considering the university being connected with professional associations beneficial', 'the internship being beneficial to those that will be employed in public relations' and having more elective courses than mandatory ones will be beneficial (F4), 
intentional and voluntary selection of public relations department and considering the public relations education in state and private universities to be different (F6), the high number of communication faculties will lead to employment issues in public relations field and considering the public relations education in state and private universities to be different in this respect (F7) and general status of the scale compared to men.

Men, on the other hand, have higher opinions than women on agreeing with the professional foreign language courses and use of foreign material in public relations education' and 'considering it more effective to work in public relations while also studying it (F3).

\section{Analysis of Difference by Age}

The relation between the scale and its dimensions and age groups has been examined by Kruskal Wallis Analysis. The analysis results are provided in Table 2.

Table 2. Analysis of Difference by Age

\begin{tabular}{|c|c|c|c|c|c|c|}
\hline Dimensions & Age & $\mathbf{N}$ & $\begin{array}{c}\text { Average of } \\
\text { Lines }\end{array}$ & $\begin{array}{l}\text { Chi } \\
\text { Square }\end{array}$ & Sd & $\begin{array}{c}p \\
\text { Value }\end{array}$ \\
\hline \multirow{6}{*}{ F1 } & $17-21$ & 153 & 255,62 & \multirow{5}{*}{20,979} & \multirow{5}{*}{4} & \multirow{5}{*}{0,000} \\
\hline & $22-26$ & 258 & 276,36 & & & \\
\hline & $27-31$ & 63 & 200,28 & & & \\
\hline & $32-36$ & 3 & 444,00 & & & \\
\hline & 37 and above & 52 & 304,34 & & & \\
\hline & Total & 529 & & & & \\
\hline & & & & & & \\
\hline \multirow{6}{*}{ F2 } & $17-21$ & 153 & 274,61 & \multirow{5}{*}{1,875} & \multirow{5}{*}{4} & \multirow{5}{*}{0,759} \\
\hline & $22-26$ & 258 & 264,63 & & & \\
\hline & $27-31$ & 63 & 252,94 & & & \\
\hline & $32-36$ & 3 & 318,00 & & & \\
\hline & 37 and above & 52 & 250,14 & & & \\
\hline & Total & 529 & & & & \\
\hline \multirow{7}{*}{ F3 } & & & & & & \\
\hline & $17-21$ & 153 & 286,31 & \multirow{5}{*}{80,079} & \multirow{5}{*}{4} & \multirow{5}{*}{0,000} \\
\hline & $22-26$ & 258 & 298,48 & & & \\
\hline & $27-31$ & 63 & 126,52 & & & \\
\hline & $32-36$ & 3 & 78,00 & & & \\
\hline & 37 and above & 52 & 214,73 & & & \\
\hline & Total & 529 & & & & \\
\hline & & & & \multirow{6}{*}{47,790} & & \\
\hline \multirow{6}{*}{ F4 } & $17-21$ & 153 & 219,09 & & \multirow{5}{*}{4} & \multirow{5}{*}{0,000} \\
\hline & $22-26$ & 258 & 308,83 & & & \\
\hline & $27-31$ & 63 & 255,33 & & & \\
\hline & $32-36$ & 3 & 126,50 & & & \\
\hline & 37 and above & 52 & 202,32 & & & \\
\hline & Total & 529 & & & & \\
\hline & & & & & & \\
\hline \multirow{6}{*}{ F5 } & $17-21$ & 153 & 264,90 & \multirow{5}{*}{35,062} & \multirow{5}{*}{4} & \multirow{5}{*}{0,000} \\
\hline & $22-26$ & 258 & 289,69 & & & \\
\hline & $27-31$ & 63 & 228,87 & & & \\
\hline & $32-36$ & 3 & 454,00 & & & \\
\hline & 37 and above & 52 & 175,69 & & & \\
\hline & Total & 529 & & & & \\
\hline F6 & $17-21$ & 153 & 305,67 & 99,831 & 4 & 0,000 \\
\hline
\end{tabular}




\begin{tabular}{|c|c|c|c|c|c|c|}
\hline & $22-26$ & 258 & 213,02 & & & \\
\hline & $27-31$ & 63 & 399,09 & & & \\
\hline & $32-36$ & 3 & 449,50 & & & \\
\hline & 37 and above & 52 & 230,12 & & & \\
\hline & Total & 529 & & & & \\
\hline & & & & \multirow{6}{*}{84,167} & & \\
\hline \multirow{6}{*}{ F7 } & $17-21$ & 153 & 284,33 & & \multirow{5}{*}{4} & \multirow{5}{*}{0,000} \\
\hline & $22-26$ & 258 & 274,75 & & & \\
\hline & $27-31$ & 63 & 320,02 & & & \\
\hline & $32-36$ & 3 & 298,00 & & & \\
\hline & 37 and above & 52 & 91,15 & & & \\
\hline & Total & 529 & & & & \\
\hline & & & & & & \\
\hline \multirow{6}{*}{$\begin{array}{l}\text { General Status of } \\
\text { Scale }\end{array}$} & $17-21$ & 153 & 258,03 & \multirow{5}{*}{29,613} & \multirow{5}{*}{4} & \multirow{5}{*}{0,000} \\
\hline & $22-26$ & 258 & 295,46 & & & \\
\hline & $27-31$ & 63 & 209,59 & & & \\
\hline & $32-36$ & 3 & 331,50 & & & \\
\hline & 37 and above & 52 & 197,67 & & & \\
\hline & Total & 529 & & & & \\
\hline
\end{tabular}

The analysis of Table 2 is as follows:

Factor2 (F2); The expressions 'the successful use of new technologies in curriculum', 'considering wages paid to public relations employees to be good', 'public relations employees being mostly women', 'believing the university aids its students with respect to internship' show no statistically meaningful variation by age $(p>0.05)$.

However, factors displaying statically meaningful variation by age are as follows:

Factor1 (F1); the general status of the expressions 'finding the theoretical and applied course hours in public relations departments to be adequate' and 'the education received from such departments being adequate in quality and standards for employment and at global standards' show statistically meaningful variation by age $(p<0.05)$.

Factor3 (F3); the general status of the expressions 'agreeing with the professional foreign language courses and use of foreign material in public relations education' and 'considering it more effective to work in public relations while also studying it' show statistically meaningful variation by age $(p<0.05)$.

Factor4 (F4); the general status of the expressions 'considering the university being connected with professional associations beneficial', 'the internship being beneficial to those that will be employed in public relations' and having more elective courses than mandatory ones will be beneficial' show statistically significant variation by age $(p<0.05)$.

Factor5 (F5); agreeing with the University requiring mandatory internship from students in public relations departments and considering public relations employees as prestigious show statistically significant variation by age $(p<0.05)$.

Factor6 (F6); the general status of the expressions intentional and voluntary selection of public relations department and considering the public relations education in state and private universities to be different show statistically significant variation by age $(p<0.05)$.

Factor7 (F7); the general status of the expressions the high number of communication faculties will lead to employment issues in public relations field and considering the public relations education in state and private universities to be indifferent in this respect show statistically significant variation by age $(p<0.05)$.

According to these results, people whose ages between $\mathbf{2 7}$ and $\mathbf{3 1}$ have higher opinions on 'finding the theoretical and applied course hours in public relations departments to be adequate' and 
'the education received from such departments being adequate in quality and standards for employment and at global standards' (F1) than other age groups.

That people whose ages between 22 and 26 have higher opinions on intentional and voluntary selection of public relations department and considering the public relations education in state and private universities to be different (F6) than other age groups is seen.

People whose ages between 32 and 36 have higher opinions on agreeing with the professional foreign language courses and use of foreign material in public relations education and considering it more effective to work in public relations while also studying it (F3) and considering the university being connected with professional associations beneficial', the internship being beneficial to those that will be employed in public relations' and having more elective courses than mandatory ones will be beneficial (F4) than other age groups.

People whose ages are 37 and above have higher opinions on agreeing with the University requiring mandatory internship from students in public relations departments and considering public relations employees as prestigious (F5), the high number of communication faculties will lead to employment issues in public relations field and considering the public relations education in state and private universities to be indifferent (F7) and general status (general status of scale) than other age groups.

\section{Analysis of Difference by Education Level}

The relationship between education level groups with their scales and sizes has been examined by Kruskal Wallis Analysis. The analysis results are provided in Table 3 .

Table 3. Analysis of Difference by Education Level

\begin{tabular}{|c|c|c|c|c|c|c|}
\hline Dimension & Gender & $\mathbf{N}$ & $\begin{array}{l}\text { Average of } \\
\text { Lines }\end{array}$ & $\begin{array}{c}\text { Chi } \\
\text { Square }\end{array}$ & Sd & $\begin{array}{c}p \\
\text { value }\end{array}$ \\
\hline \multirow{4}{*}{ F1 } & Undergraduate & 421 & 235,33 & \multirow{3}{*}{81,795} & \multirow{3}{*}{2} & \multirow{3}{*}{0,000} \\
\hline & Post Graduate & 66 & 402,90 & & & \\
\hline & Doctorate & 42 & 345,75 & & & \\
\hline & Total & 529 & & & & \\
\hline & & & & & & \\
\hline \multirow{4}{*}{ F2 } & Undergraduate & 421 & 235,39 & \multirow{3}{*}{78,882} & \multirow{3}{*}{2} & \multirow{3}{*}{0,000} \\
\hline & Post Graduate & 66 & 388,42 & & & \\
\hline & Doctorate & 42 & 367,83 & & & \\
\hline & Total & 529 & & & & \\
\hline \multirow{5}{*}{ F3 } & & & & & & \\
\hline & Undergraduate & 421 & 279,81 & \multirow{3}{*}{21,119} & \multirow{3}{*}{2} & \multirow{3}{*}{0,000} \\
\hline & Post Graduate & 66 & 219,06 & & & \\
\hline & Doctorate & 42 & 188,79 & & & \\
\hline & Total & 529 & & & & \\
\hline & & & & & & \\
\hline \multirow{4}{*}{ F4 } & Undergraduate & 421 & 282,05 & \multirow{3}{*}{26,483} & \multirow{3}{*}{2} & \multirow{3}{*}{0,000} \\
\hline & Post Graduate & 66 & 194,85 & & & \\
\hline & Doctorate & 42 & 204,35 & & & \\
\hline & Total & 529 & & & & \\
\hline & & & & & & \\
\hline \multirow{4}{*}{ F5 } & Undergraduate & 421 & 277,08 & \multirow{3}{*}{34,271} & \multirow{3}{*}{2} & \multirow{3}{*}{0,000} \\
\hline & Post Graduate & 66 & 269,03 & & & \\
\hline & Doctorate & 42 & 137,60 & & & \\
\hline & Total & 529 & & & & \\
\hline \multirow[b]{2}{*}{ F6 } & Undergraduate & 421 & 266,60 & \multirow[b]{2}{*}{8,255} & \multirow[b]{2}{*}{2} & \multirow[b]{2}{*}{0,016} \\
\hline & Post Graduate & 66 & 226,14 & & & \\
\hline
\end{tabular}




\begin{tabular}{|c|c|c|c|c|c|c|}
\hline & Doctorate & 42 & 310,04 & & & \\
\hline & Total & 529 & & & & \\
\hline & & & & & & \\
\hline & Undergraduate & 421 & 265,61 & & & \\
\hline & Post Graduate & 66 & 338,11 & 44,099 & 2 & 0,000 \\
\hline $\mathbf{r}$ & Doctorate & 42 & 144,00 & & & \\
\hline & Total & 529 & & & & \\
\hline & & & & & & \\
\hline & Undergraduate & 421 & 247,33 & & & \\
\hline & Post Graduate & 66 & 371,28 & 37,858 & 2 & 0,000 \\
\hline $\begin{array}{l}\text { Status ot } \\
\text { Scale }\end{array}$ & Doctorate & 42 & 275,07 & & & \\
\hline & Total & 529 & & & & \\
\hline
\end{tabular}

The factors displaying or not displaying a significant variation statistically by education level in Table 3 are as follows:

Factor1 (F1); the general status of the expressions 'finding the theoretical and applied course hours in public relations departments to be adequate' and 'the education received from such departments being adequate in quality and standards for employment and at global standards' show statistically meaningful variation by education level $(p<0.05)$.

Factor2 (F2); the general status of the expressions 'the successful use of new technologies in curriculum', 'considering wages paid to public relations employees to be good', 'public relations employees being mostly women', 'believing the university aids its students with respect to internship' show statistically meaningful variation by education level $(p<0.05)$.

Factor3 (F3); general status of the expressions 'agreeing with the professional foreign language courses and use of foreign material in public relations education' and 'considering it more effective to work in public relations while also studying it' show statistically meaningful variation by education level. $(p<0.05)$.

Factor4 (F4); the general status of the expressions 'considering the university being connected with professional associations beneficial', 'the internship being beneficial to those that will be employed in public relations' and having more elective courses than mandatory ones will be beneficial' show statistically meaningful variation by education level $(p<0.05)$.

Factor5 (F5); agreeing with the University requiring mandatory internship from students in public relations departments and considering public relations employees as prestigious show statistically meaningful variation by education level $(p<0.05)$.

Factor6 (F6); the general status of the expressions intentional and voluntary selection of public relations department and considering the public relations education in state and private universities to be different show statistically meaningful variation by education level $(p<0.05)$.

The general status of the expressions the high number of communication faculties will lead to employment issues in public relations field and considering the public relations education in state and private universities to be indifferent (F7) in this respect show statistically meaningful variation by education level $(p<0.05)$.

According to these results, undergraduate people have higher opinions on finding the theoretical and applied course hours in public relations departments to be adequate and the education received from such departments being adequate in quality and standards for employment and at global standards, (F1), the successful use of new technologies in curriculum, considering wages paid to public relations employees to be good, public relations employees being mostly women, believing the university aids its students with respect to internship (F2) and general status (general status of scale) compared to people on other levels of education. Postgraduate people have higher opinions on considering the university being connected with professional associations beneficial, the internship being beneficial to those that will be employed in public relations and having more elective courses 
than mandatory ones will be beneficial (F4) and intentional and voluntary selection of public relations department and considering the public relations education in state and private universities to be different (F6) than people on other levels of education. Doctorate people have higher opinions on agreeing with the professional foreign language courses and use of foreign material in public relations education and considering it more effective to work in public relations while also studying it (F3), agreeing with the University requiring mandatory internship from students in public relations departments and considering public relations employees as prestigious (F5) and the high number of communication faculties will lead to employment issues in public relations field and considering the public relations education in state and private universities to be indifferent (F7) compared to people on other levels of education.

\section{Analysis of Difference by Occupation}

The relationship between scale and extents and occupational groups has been examined by Kruskal Wallis Analysis. The analysis results are provided in Table 4.

Table 4. Analysis of Difference by Occupation

\begin{tabular}{|c|c|c|c|c|c|c|}
\hline Dimensions & Age & $\mathbf{N}$ & $\begin{array}{l}\text { Average of } \\
\text { Lines }\end{array}$ & $\begin{array}{c}\text { Chi } \\
\text { Square }\end{array}$ & Sd & p Value \\
\hline \multirow{6}{*}{ F1 } & Student & 295 & 264,67 & \multirow{5}{*}{126,285} & \multirow{5}{*}{4} & \multirow{5}{*}{0,000} \\
\hline & Self-employment & 18 & 370,22 & & & \\
\hline & Wage earner & 120 & 159,74 & & & \\
\hline & Unemployed & 29 & 443,88 & & & \\
\hline & Other & 67 & 349,30 & & & \\
\hline & Total & 529 & & & & \\
\hline \multirow{6}{*}{ F2 } & Student & 295 & 307,95 & \multirow{5}{*}{188,595} & \multirow{5}{*}{4} & \multirow{5}{*}{0,000} \\
\hline & Self-employment & 18 & 285,31 & & & \\
\hline & Wage earner & 120 & 115,83 & & & \\
\hline & Unemployed & 29 & 461,17 & & & \\
\hline & Other & 67 & 252,72 & & & \\
\hline & Total & 529 & & & & \\
\hline \multirow{6}{*}{ F3 } & Student & 295 & 304,80 & \multirow{5}{*}{75,706} & \multirow{5}{*}{4} & \multirow{5}{*}{0,000} \\
\hline & Self-employment & 18 & 365,72 & & & \\
\hline & Wage earner & 120 & 196,98 & & & \\
\hline & Unemployed & 29 & 277,69 & & & \\
\hline & Other & 67 & 179,04 & & & \\
\hline & Total & 529 & & & & \\
\hline \multirow{6}{*}{ F4 } & Student & 295 & 273,99 & \multirow{5}{*}{94,410} & \multirow{5}{*}{4} & \multirow{5}{*}{0,000} \\
\hline & Self-employment & 18 & 314,86 & & & \\
\hline & Wage earner & 120 & 331,48 & & & \\
\hline & Unemployed & 29 & 207,34 & & & \\
\hline & Other & 67 & 117,90 & & & \\
\hline & Total & 529 & & & & \\
\hline \multirow{6}{*}{ F5 } & Student & 295 & 224,66 & \multirow{5}{*}{72,776} & \multirow{5}{*}{4} & \multirow{5}{*}{0,000} \\
\hline & Self-employment & 18 & 288,08 & & & \\
\hline & Wage earner & 120 & 348,78 & & & \\
\hline & Unemployed & 29 & 353,84 & & & \\
\hline & Other & 67 & 247,90 & & & \\
\hline & Total & 529 & & & & \\
\hline
\end{tabular}




\begin{tabular}{|c|c|c|c|c|c|c|}
\hline \multirow{6}{*}{ F6 } & Student & 295 & 280,45 & \multirow{6}{*}{40,121} & \multirow{5}{*}{4} & \multirow{5}{*}{0,000} \\
\hline & Self-employment & 18 & 363,89 & & & \\
\hline & Wage earner & 120 & 249,43 & & & \\
\hline & Unemployed & 29 & 117,91 & & & \\
\hline & Other & 67 & 261,95 & & & \\
\hline & Total & 529 & & & & \\
\hline \multirow{6}{*}{ F7 } & Student & 295 & 25949 & \multirow{5}{*}{6,150} & \multirow{5}{*}{4} & \multirow{5}{*}{0,188} \\
\hline & Self-employment & 18 & 219.03 & & & \\
\hline & Wage earner & 120 & 263,61 & & & \\
\hline & Unemployed & 29 & 312,07 & & & \\
\hline & Other & 67 & 283,73 & & & \\
\hline & Total & 529 & & & & \\
\hline \multirow{6}{*}{$\begin{array}{l}\text { General State of } \\
\text { the Scale }\end{array}$} & Student & 295 & 287.89 & \multirow{5}{*}{102,352} & \multirow{5}{*}{4} & \multirow{5}{*}{0,000} \\
\hline & Self-employment & 18 & 360,97 & & & \\
\hline & Wage earner & 120 & 166,81 & & & \\
\hline & Unemployed & 29 & 437,40 & & & \\
\hline & Other & 67 & 239,65 & & & \\
\hline & Total & 529 & & & & \\
\hline
\end{tabular}

The factors not displaying meaningful variation by occupation in Table 4 are as follows:

Factor 7 (F7); the expressions of the high number of communication faculties will lead to employment issues in public relations field and considering the public relations education in state and private universities to be indifferent in this respect show no statistically significant variation by occupation $(p>0.05)$.

follows:

The factors displaying meaningful variation statically by occupation in Table 26 are as

Factor1 (F1); the general status of the expressions 'finding the theoretical and applied course hours in public relations departments to be adequate' and 'the education received from such departments being adequate in quality and standards for employment and at global standards' show statistically meaningful variation by occupation $(p<0.05)$.

Factor2 (F2); the general status of the expressions 'the successful use of new technologies in curriculum', 'considering wages paid to public relations employees to be good', 'public relations employees being mostly women', 'believing the university aids its students with respect to internship' show statistically meaningful variation by occupation $(p<0.05)$.

Factor3 (F3); the general status of the expressions 'agreeing with the professional foreign language courses and use of foreign material in public relations education' and 'considering it more effective to work in public relations while also studying it' show statistically meaningful variation by occupation $(p<0.05)$.

Factor4 (F4); the general status of the expressions 'considering the university being connected with professional associations beneficial', 'the internship being beneficial to those that will be employed in public relations' and having more elective courses than mandatory ones will be beneficial' show statistically meaningful variation by occupation $(p<0.05)$.

Factor5 (F5); agreeing with the University requiring mandatory internship from students in public relations departments and considering public relations employees as prestigious show statistically meaningful variation by occupation $(\mathrm{p}<0.05)$.

Factor6 (F6); the general status of the expressions intentional and voluntary selection of public relations department and considering the public relations education in state and private universities to be different show statistically meaningful variation by occupation $(p<0.05)$. 
According to these results, wage earners have higher opinions on finding the theoretical and applied course hours in public relations departments to be adequate and the education received from such departments being adequate in quality and standards for employment and at global standards (F1), the successful use of new technologies in curriculum, considering wages paid to public relations employees to be good, public relations employees being mostly women, believing the university aids its students with respect to internship (F2) and general status (general status of scale) than people in other occupational groups.

People in other occupational groups have higher opinions on agreeing with the professional foreign language courses and use of foreign material in public relations education and considering it more effective to work in public relations while also studying it (F3) and considering the university being connected with professional associations beneficial, the internship being beneficial to those that will be employed in public relations and having more elective courses than mandatory ones will be beneficial (F4) than people in other groups. Students have higher opinions on agreeing with the University requiring mandatory internship from students in public relations departments and considering public relations employees as prestigious (F5) than people in other occupational groups. Unemployed people have higher opinions on intentional and voluntary selection of public relations department and considering the public relations education in state and private universities to be different (F6) than people in other occupational groups.

\section{Conclusion}

Public relations have originated from a practice rather than a discipline. In other words, it has been shaped, changed and developed, being influenced by time-dependent changes and dynamics. In this context, its definitions and its development on the historical process have also varied. As stated by Tuncel (2009), public relations was defined with various names as 'public benefit' in 1882, 'promotion' in the late 19th century, 'press agency - promotion management' in 1920s, 'social behavior guide' goodwill developer - persuasive ' 1940's; in the 1950s and 1960s, then it was called as 'softeners-promoter-news engineer' in 1950s and 1960s, being applied to metaphors. For the practitioners of the public relations, they were called as 'parrots - the law of the devil - the voice of the owner'. In time, Images making and public relations have been mentioned together, and in the later processes public relations was defined as 'spin doctor and flack' in the United States in 1980s. When the effects of public relations began to be felt in our country in 1990, the current definitions and the image began uncomfortably with "the approach based making news as events model-like, beautiful women like in urban legends participated in". (Tuncel, 2009: 119).

At the same time, all these different definitions and interpretations show that public relations is a field of application, and it is like a craft handed down from master to apprentice. It would not be wrong to say that a combination of a little talent, a little experience, a little instinct, and a little theory would lead to a perfect public relations practitioner. There are many discussions and comments about what and how the education should be in the universities on the process of creating the perfect public relations practitioner. When the available data is examined, that the curriculum union between universities is provided for the main courses on theoretical lectures, on scientific preparation courses related to courses in communication is seen. Providing a common curriculum in the main courses for the students is useful for the provision of educational unity. And making a statement, providing different choices to the students in optional courses would be more useful and also important detail for public relations education so as to reach to the global standards. Particularly in the optional courses, a multitude of course alternatives presented in accordance with the students' interests and the age's requirements would be effective in increasing the interdisciplinary knowledge efficiency in the field of public relations and educating individuals to have cultural richness. Public relations have an interdisciplinary structure and benefit from social sciences by including them. Public relations are normative like law, but this situation changes according to the application. As a result of this structure, the first-year courses such as "Introduction to Communication Sciences - Introduction to the Public relations" courses; second-year courses as 'applications of public relations - introduction to sociology, Psychology and Communication theories' are required to be given as a curriculum standard. For the third-year and fourth-year courses, an education approach as decreasing hours of theoretical courses being specific, restricting and triggering specialization and increasing hours of practical course would be more beneficial for the students. In this context, the subject basic communication information given, is taken in the undergraduate degree, and since they cannot be taken in associate degree, this course cannot be accepted as a post-business course. One of the details that should not be forgotten at this 
point is that public relations can be advertising but public relations are not marketing. It is also clear that the applications and activities for the sector should be increased in the curriculum as a necessity of the age no matter university education has an intellectual characteristic. The curriculums on which major practitioners, who give courses, from the sector have reinforced to the teachings on theory with their experiences and knowledge will shed light on young people having spent years stressing over exams and having fears of not finding a job in the future. Thus, the academy both will raise intellectual individuals who research and study and will be the controlling power to help the professionals, who can apply their skills acquired from the academy to business life, get a job. Such practices will make positive contribution to the prestige of universities.

The Sector's expectation from graduated students is putting the things they learned into practice as a corporation. The sector, in this expectation, being expactant of this, mentioning the intense work of the sector and shortage of time, shows a little callous approach in not sharing its knowledge and experiences with the university students practically; which this situation is widely criticized by the universities and students. For realizing the big expectation of the sector, the limited support it provides to the students and graduates contrasts with this expectation. That the criticism, which the sector often makes about the graduates that they remain incapable in theory and practicing, is not expressed with tangible data causes it to be unclear for the students and graduates. Here repeating the joke that Metin Kazancı tells in Tuesday meetings is actually an answer to both sector and students' criticisms about university education (2014: 187); a man calls a craftsman because his boiler malfunctions. After the craftsmen looks at it and hits it once boiler starts to work. After the man thanks craftsman and asks the charge of it, he surprises and speaks out that when he hears the craftsman wants 100 Turkish liras. Thereupon craftsman says it is not too much. 5 Liras for hitting with hammer and 95 liras for knowing where to hit with hammer and the joke ends here. The situation is the same for the faculties of communication, too. It is essential to know the theories and methods taught in the classes for students, however, the main thing the faculty should give the students is knowing where to hit the hammer and learning where, when and how to use the information they learned. Based on this joke that expresses the effect of how the practice is shaped and implemented, we encounter with the necessity of theoretical and practical education should be any more unified within the faculty education due to today's conditions.

Students and their families endeavoring for years to be able to get into a four-year university are eager to see the university education as both an intellectual environment and a source that prepares them to life. In this context, if universities provide the practice while transferring the intellectual background with theoretical education, they integrate their graduate students into the sector as qualified practitioners from their own constitution. In this way, they become the source where the new pioneers grow. It is necessary for providing a healthy and qualified cycle. While the students being able to benefit from other disciplines and having an acceptable knowledge in these disciplines are the choices of the sector, it is important that universities providing education on public relations should question "the conscious and structure of being a university". The important decision should be made is the subject of "whether the university education style should be changed or not" and so, will the universities teach science to the students? Or will they teach profession and prepare them to the sector? These questions are not kind of questions that are evaluated separately from each other. A point that is emphasized from the beginning and that academicians underline mainly is that 'the faculty doesn't aim at teaching profession like in associate degree programs and it has and should an education concept that aims to make them think, question, research, criticize and understand why they do what they do by giving scientific idea and'. The conditions of being a university have already been emphasized in details in this scientific structure four years of education given in. However, if we take the motion and the structure open to the change and improvement of public relations in years into consideration, it is necessary that public relations educations in the universities should include sectoral expectation and professional experience for individuals finding jobs to be able to continue their lives and earning money as a necessity of the age. At this point, while in the preparation to the university or in the university preference times, it is necessary that students should decide whether they study public relations or not, what they will study and learn in this department and what they will be and what they want to be at the beginning. The students preferring this department just to study commonly, not thinking to work on this field in the future or not thinking being an academician on this field already move away from the goals of the education given in this department and they decrease the quality standards of the department. For this reason, while meeting with students on the university preference period, the detailed information about public relations education and what actually the university education is should be given. 
Even though it looks as if there are too many options for people due to the increasing number of universities and departments, it also causes current standard and quality to be decreased. The lack of quality and quantity within the structure of staff that can give education on the field gets sharper with the public relations department in each newly opened university and causes to the increasing of criticism by decreasing the standards of public relations education. And it is inevitable to the revision of education structure in the country about this topic.

As an another approach, the universities should make a scientific and sectoral distinction to the education particularly from the third-grade by dividing as the students wanting to be academicians by taking scientific education and as students thinking to work in the sector on public relations by softening and revising their perspectives. Such distinction will provide averting the questions like 'why do I take this class or what does it have to with my preferences'. Besides, by averting criticisms coming from the sector and catching a certain standard on professionalization, it will be easy to catch the desired reputation.

Public relations education given in our country has features that can be criticized in terms of free thinking and acting, criticizing, producing new things by specializing according to fields of interest, not in terms of being under the global standards. The hesitation of students on even studying or researching freely in a subject they want is not only a problem of public relations department, but also a problem of the country in general. Individuals, removed from studying according to their fields of interest by being far away from free thinking, researching and socio-economical concerns, are tried to be directed with a parrot fashion, restricted concept and not to be improved in terms of general knowledge. To provide academical, sectoral and social improvement, it is necessary to remember that there should be 'genuine studies realized by free universities.'

\section{References}

[1] Asna, A. (2012). Kuramda ve Uygulamada Halkla İlişkiler, Pozitif Yayınları, İstanbul.

[2] Aziz, A. (2015). Sosyal Bilimlerde Araştırma Yöntemleri ve Teknikleri, Nobel Akademik Yayıncılık, Ankara.

[3] Balcı, A. (2008). Türkiye'de Eğitim Yönetiminin Bilimleşme Düzeyi, Kuram ve Uygulamada Eğitim Yöntemi, sayı:53.

[4] Baskin, O., Aronoff, C. ve Lattimore D. (1997). Public Relations The Profession and the Practice, 4th Edition, Madison, WI.

[5] Bentele, G. (1997). PR Histographie und funktional-integrative Schichtung: Einneuer Ansatz zur PR- Geschichtsschreibung, Peter Szyska (Ed.), Auf der Suche nach Identitaet: PR Geschichte als Theoriebaustein içinde, Vistas, Berlin 137-169.

[6] Bentele, G. ve Yunghaenel, I. (2004). Betteke van Ruler ve Dejan Vercic (Ed.), Prand Communication Managment in Europa içinde, Mouton de Gruyter, Germany.

[7] Berth, K. ve Sjöberg, G. (1998). Halkla İlişkiler Eğitiminin Evrimi ve Küreselleşmenin EtkisiSekiz Ülke Üzerine İnceleme, Altın Kitap Serisi. Sayı:12, Rota Yayınları, İstanbul.

[8] Black, S. (1998), Halkla Illişkiler Eğitimi. Çev. Nur Nirven ve Ahmet Ünver.1. Basım. IPRAUluslararası Halkla İlişkiler Derneği Altın Kitap Serisi. Sayı:7, Rota Yayınları, İstanbul.

[9] Boztepe, H. (2014). Kamusal Halkla İlişkiler, Der Kitabevi, İstanbul.

[10] Canpolat, N. (2013), Türkiye'de Halkla IIlişkiler Eğitimi: Halkla Illişkiler Ders Programlarının Değerlendirilmesine Yönelik Bir Araştırma, Gümüşhane Üniversitesi İletişim Fakültesi Elektronik Dergisi, cilt:2, sayı:2.

[11] Choi, J. (2007). Elaborating the Concept of Public Relations Roles and A Test of Its Utilitiy, (yayınlanmamış doktora tezi), Michigan State University, UMI Dissertation Information Service.

[12] Coombs,W. ve Timothy, R. K. (1999). Public Relations Education: Where Is Pedagogy?. Public Relations Review. Volume:25. Number:1. Elsevier Science Inc.

[13] Cotton, A.M ve Tench, R. (2009). Profiling the Public Relations Undergraduate/Bechelor and Graduate/Master Programmes in Europe and Beyond, Berlin Spring Sumposium, www. euprera. org, access: 13.12.2016.

[14] Dozier, D. M. (2005). Illetişim ve Halkla İlişkiler Uygulayıcılarının Örgütsel Rolleri,

[15] J. E. Grunig (ed), Halkla İlişkiler ve İletişim Yönetiminde Mükemmellik, Elif Özsayar (çev.), İstanbul: Rota Yayın Yapım Dağıtım, 349- 377. 
[16] Erdem, A. ve Akbaba, E. (2007). Halkla ilişkiler Nedir? Ne Değildir?, Metin Işık (ed), Tüm Yönleriyle Halkla İlişkiler ve Tanıtım, Eğitim Kitabevi, Konya.

[17] Erendağ, F. (2004). Halkla İlişkiler Eğitimi,Türkiye ve ABD'deki Lisans Düzeyi Halkla İlişkiler Müfredat Programlarının Karşılaştırılması, Akdeniz Ünversitesi Sosyal Bilimler Enstitüsü Halkla Illişkiler Ve Tanıtım Ana Bilim Dalı, (yüksek lisans tezi), Antalya.

[18] Gölönü, S. (2006). Gelişen Teknolojiler, Öğrenen Örgütler ve Halkla İlişkiler. Journal Of Selcuk Communication, Sayı:3 Cilt: 4, Konya.

[19] Grunig L.A., Grunig, J. E. ve Dozier, D. M. (2002). Excellent Public Relations and Effective Organizations: A Study of Communication Management in Three Countries, Mahwah, New Jersey: Lawrence Erlbaum Associates.

[20] Grunig, J. E. (2005). Halkla İlişkiler Ve Illetişim Yönetiminde Mükemmellik, Elif Özsayar (çev.), Rota Yayınları, İstanbul.

[21] Kalender, A. (2013). Kavramsal Olarak Halkla Ilişkiler, Dünyada ve Türkiye'de Halkla Illişkilerin Tarihsel Gelişimi, Halkla İlişkiler, T.C. Anadolu Üniversitesi Yayın No: 2713, Açıköğretim Fakültesi Yayını No: 1676, Aydın Ziya Özgür (ed.).

[22] Karasar, N. (2004) . Bilimsel Araştırma Yöntemi (12.Basım). Nobel yayıncılık, Ankara. Kocbaş, F., Pira, A. ve Sohodol, S. (2004). Halkla Illişkiler Eğitiminin Kalitesinin Artırılmasında Eğitimci-Uygulamacı-Öğrenci Rolleri ve İşbirliği: Mevcut Durum ve Öneriler Üzerine Bir Araştırma, II. Uluslar arası Sempozyum: Milenyumda İletişim: Türk ve Amerikan Akademisyenleri Arasında Bir Diyalog, 17-19 Mart 2004, İstanbul Üniversitesi/Teksas Üniversitesi, İstanbul.

[23] Kruckeberg, D. (1998). The Future of PR Education: Some Recommendations, Public Relations Review, 24(2).

[24] Matellart, A. (1995). Uneqal Voices. (The Multimedia Explosion:Quo Vadis?), UNESCO Courier, U.S.A.

[25] McQuail, D. ve Windahl, S.(2005). Kitle İletişim Çalışmalarında İletişim Modelleri, Çev: Konca Yumlu, İstanbul: İmge Yayınları.

[26] Oeckl, A. (1998). Dünyada Halkla Illişkiler Eğitimi, IPRA Altın Kitap Serisi, sayı:2, Rota Yayınları, İstanbul.

[27] Peltekoğlu, B. F. (2007). Halkla Illişkiler Nedir?, Beta Yayınları, İstanbul.

[28] Tanyıldız, İ.N. ve Serttaş, A. (2013). Türkiye ve Amerika Birleşik Devletleri'nde Halkla Illişkilerin Gelişimi, International Journal of Social Science, Doi nr: http://dx.doi.org/10.9761/JASSS1724 Vol.6 Issue 6.

[29] Ural, G. E. (2012). Etkili Bir Halkal İlişkiler Lisans Eğitimi İçin Halkla İlişkiler Alanında Ortaya Çıkan Değişimlerin Eğitimie Aktarılması, e-Journal Of New World Science Academy, volume:7, Number:2, Article Number: 3C0095.

[30] Van het Hof, S. ve Tuncer, U. (2011). Halkla Illişkiler Eğitimi Üzerine Bir Eleştiri, Akdeniz Üniversitesi İletişim Fakültesi, Akdeniz İletişim Dergisi, sayı:15. Yengin, D. (2017). İletişim Çalışmalarında Araştırma Yöntemleri ve Uygulamaları, İstanbul, Der Yayınları. 